\section{Reference Books}

Carolyn J. Radcliff

Editor

African Americans in the Media Today: An Encyclopedia. Ed. by Sam G Riley. Westport, Conn.: Greenwood, 2007. 2 vols. alkaline \$175 (ISBN 978-0-313-33679-9).

This handy two-volume set, edited by Sam G. Riley, consists of brief biographical sketches of more than 250 African Americans currently or formerly employed in the U.S. news media. Riley, a professor at Virginia Polytechnic University, has created a well-organized and unique reference work. The collection covers syndicated and local columnists, broadcast news figures, magazine figures, sports columnists, sportscasters, editors, and more.

Each entry includes basic biographical information: date of birth, education, career details, and so on. The entries also present individuals' positions on relevant issues. For example, the sketch on Marcus Mabry, chief of correspondents for Newsweek, contains his views on such topics as Americans' unawareness of international news and Hurricane Katrina. Each sketch includes a list of further readings and some sketches include original documents, such as newspaper columns written by the individual profiled. For example, the entry for C. Gerald Fraser, a veteran columnist, contains the full article he wrote about the significance for African American journalists of the Jayson Blair scandal.

The biographies are organized alphabetically. Included in volume 1 is a list of entries organized by profession and a chronology of key events for African Americans in the news media. Volume 2 contains a thirteen-page bibliography.

African Americans in the Media Today is the only encyclopedia of its kind to provide a convenient source for biographies in this important and surprisingly neglected subject area. Overall, this reference set is an exceptional resource for any academic or public library. It will be particularly useful for college students researching African American Studies or journalism topics. Recommended for public and college libraries._Colleen Lougen, Electronic Resources Librarian, State University of New York, New Paltz

Career Opportunities in Conservation and the Environment. Paul Greenland and Anna Marie Sheldon. New York: Ferguson, 2008. 336p. acid free \$49.50 (ISBN 978-0-8160-6742-8).

Resources on career opportunities are among the most popular titles in all libraries. With a much-heightened interest in "going green," Career Opportunities in Conservation and the Environment is a timely publication for those interested in learning more about various career options related to conservation and the environment.

The sixty-nine job profiles are organized into seven sections: Ecotourism (camp counselor, wilderness guide), Engi- neering (surveyor, geospatial engineer), Farming and Fishing (crop scientist, rural appraiser), Forestry (logger, urban forester), Legal and Regulatory (park manager, fish and wildlife officer), Outdoor/Environmental Education (marine science instructor, recreation planner), and Scientific (geoscientist, oceanographer). Each section contains between three and fifteen profiles. Job profiles are three to four pages in length and provide information on salaries, employment prospects, a detailed position description, education and training requirements, advancement prospects, and a very useful "tips for entry" listing the steps that individuals can take to prepare themselves for that particular career.

The work contains several appendixes including a listing of professional associations, professional certifications, and a comprehensive directory of colleges that offer degrees and training programs organized by state for most of the jobs. A bibliography and index are included.

This is another title in the Career Opportunities series published by Ferguson Publishers, producers of the superb Encyclopedia of Careers and Vocational Guidance (Ferguson, 14th ed., 2008), a standard reference source found in most libraries. The work nicely supplements Odom Fanning's Opportunities in Environmental Careers (VGM, 2002) and The ECO Guide to Careers That Make A Difference (Island Press, 2004). This welcome addition to career resources is attractively laid out, easy to use, great for browsing or for detailed information on specific jobs. It would be useful for environmentally minded high school and college students, academic program directors, vocational program directors, and all other career development professionals._Eva Lautemann, Director of Learning Resources, Georgia Perimeter College, Clarkston

Cuba: A Global Studies Handbook. Ted Henken. Global Studies: Latin-America \& the Caribbean. Santa Barbara, Calif.: ABC-CLIO, 2008. 578p. alkaline \$55 (ISBN 978-1-85109-984-9).

Cuba: A Global Studies Handbook, by Ted Henken (Sociology and Black and Hispanic Studies, Baruch College, City University of New York), is a unique resource offering a variety of information on Cuban history, economy, and society. The first section of this work contains four chapters. "Geography and History" provides an overview of Cuba's climate, topography, flora, fauna, and conservation efforts, followed by a concise history, beginning with the pre-Columbian era and ending with the Cuban Missile Crisis. An emphasis is given to the revolutionary period. "Economics and Development" focuses on the second half of the twentieth century and includes an informative analysis of the state's often ambivalent attitudes and actions concerning the opening of the Cuban economy to private enterprise. "Institutions" describes the origins and functions of civil, political, social, and military institutions created after the 1959 revolution. Finally, "Culture and Society" covers a variety of topics including religion, the family, race, national identity, the Cuban-American community, and the arts. This chapter's detailed history of Cuban music and the many musical forms it has generated both within Cuba 


\section{SOURCES}

and in the United States will be of particular interest to lovers of Cuban music. Throughout these narratives appear black and white photographs taken by the author during his many visits to the island. Also interspersed throughout this section are sidebars providing information on many topics, including brief histories of the U.S. embargo against Cuba, Cuba's behavior modification camps for Cuban youth, the "Peter Pan" project that sent 14,000 children into exile, and Cuban publications and organizations.

The second section of this work serves as a reference source. It begins with a timeline of key events in Cuban history, followed by approximately fifty encyclopedia-style entries on significant people, places, and events. Subsequent topics include discussions of Cuban language, food, etiquette, and holidays. The work concludes with a directory of Cuba-related organizations, publications, and Web sites, followed by an annotated bibliography. Henken's discussion of the Cuban language is quite interesting. He provides details about Cuban pronunciation, slang, and grammar, as well as a list of Africanisms and Americanisms that have worked their way into Cuban vocabulary. Interestingly, he also notes the paucity of Russian words to be incorporated into the national vocabulary despite the many years of Soviet support and influence.

Cuba: A Global Studies Handbook is the first volume in a series devoted to providing "a basic introduction to some of the countries and peoples of Latin America" (xvi). Like Clifford L. Staten's The History of Cuba (Greenwood, 2003) in Greenwood's Histories of the Modern Nations series, this work provides a concise narrative of Cuba's history from prehistoric times to the present. It also includes much of the cultural information contained in William Luis's Culture and Customs of Cuba (Greenwood, 2001) one of the volumes in Greenwood's Culture and Customs of Latin America and the Caribbean series. Unlike these two volumes, however, Henken's work also includes anecdotal accounts, some humorous, some poignant, that make clear the author's love for and fascination with this country. This, combined with the work's scholarship and annotated bibliography, make Cuba: A Global Studies Handbook a valuable resource for students, academics, travelers, music lovers, and anyone interested in obtaining a personal yet always balanced account of a country that has too often been the subject of strident, biased voices on both sides of the Straits of Florida. Cuba: A Global Studies Handbook is recommended for large public and all academic libraries.-Eileen Oliver, Reference Librarian, San Antonio College Library, San Antonio, Texas

Encyclopedia of Activism and Social Justice. Ed. by Gary L. Anderson and Kathryn G. Herr. Thousand Oaks, Calif.: Sage, 2007. 3 vols. acid free \$495 (ISBN 978-1-4129-1812-1).

In the post-9/11 world, people are more and more interested in reading about topics such as globalization, world politics, and activism. It should come as no surprise that Sage Publications has produced an encyclopedia dedicated to the timely topics of activism and social justice. The editors of these three hefty volumes are professors of education and belong to a generation of scholars that kept academic discipline and activism separate. With this publication, they brought together nearly four hundred contributors and succeeded in turning a large topic into a manageable, useful encyclopedia set.

This encyclopedia is packed with information. One of the challenges with specialized encyclopedias is the creation of a navigable structure for readers. How will readers find and use this rich abundance of information? To resolve this issue, each volume in the set includes an alphabetical list of entries as well as an extremely useful reader's guide. This concise, fourteen-page section of the encyclopedia is one of its greatest assets, and provides a manageable method to help researchers navigate through the entries. An example of a heading within the reader's guide is "The Arts," with subheadings for "Literature," "Music," "Performing Arts," and "Plastic Arts." Within the subcategory for "Plastic Arts," readers will find an entry for "Mural Art." Without this type of guidance, a connection between mural art and activism might have been lost.

The editors of Encyclopedia of Activism and Social Justice should also be commended for their inclusive coverage of topics related to activism and social justice. It is noted in the introduction that they wrestled with including groups that some would label terrorists rather than activists. The defining criterion for an entry to be included was that the social justice behind an "activist" group must be clear. Therefore, readers will find an entry for Hezbollah, but not for the KKK.

To the reviewer, it is interesting and somewhat ironic that the editors owe a considerable debt to interactive online strategies in the creation of this traditional print encyclopedia. The set was greatly enhanced, according to the editors, by posting the proposed list of entries and calling for additional entries and contributors. Overall, this is an outstanding work that should be added to all academic libraries. Public libraries with an active community will also find this a worthwhile purchase. For school libraries, however, the set may be considered too advanced and academic.-Michelle S. Millet, Information Literacy Coordinator, Trinity University, San Antonio, Texas

Encyclopedia of Asian-American Literature. Seiwoong Oh. Encyclopedia of American Ethnic Literature. New York: Facts On File, 2007. 384p. acid-free \$75 (ISBN 978-0-8160-6086-3).

This volume presents 337 entries covering U.S. and Canadian authors of Asian descent. Included are more than two hundred authors writing in all genres with roots from East, Southeast and South Asia, the Middle East, the Indian subcontinent, and Hawaii. Addressing the challenge of such a broadly defined scope, the editor indicates that selection for inclusion was based on the major writers and works taught in today's high school and undergraduate programs as well as those most talked about in academic circles. He also included "several recent authors as well whose works are not yet tested but who promise to become prominent literary voices in the future" (xi). All entries in the work are signed by scholars from throughout 